\title{
On the Conceptual Shift and Collocation Between Concreteness and Abstractness-Analysis of The Mill by a New Poet in China
}

\author{
LAI Peng \\ Sun Yat-sen University, Guangzhou, China
}

\begin{abstract}
This is a poem review which analyzes The Mill that was written by a new poet in China, looking at it from the conceptual perspective. The conceptual shift and collocation between concreteness and abstractness enable her poems to carry both linguistic power and emotional strength; the conceptual images created by her abstract thinking and unique perception make her poems achieve originality and readability; her conceptual self built by the use of first person pronouns is actually not that of a person but that of a personified mule who was indignant about its heavy workload yet unable to speak against its predestined destiny. Although suffering from brain paralysis, the poet is shown by this review to be a sensible manipulator of words, which reveal the unique beauty in her language and show the suppressed sadness in her heart.
\end{abstract}

Keywords: poem review, conceptual shift, conceptual collocation, concreteness, abstractness

\section{Introduction}

In January 2015, a middle-aged woman in the countryside of Hubei Province (China) achieved overnight fame as a poet because of the sudden popularity of her poems that were spread on WeChat-a popular medium used on mobile phones by people all over China. Reporters from the news agencies flocked to her home to interview her, and agents sent by the publishers pleaded her for the right of publishing her poems. She suddenly became a person under the spotlight. Her poems brought about heated arguments among critics, readers and fellow poets. Her name is YU Xiuhua (余秀华). What’s remarkable about her is that she displayed her talents in poem-writing despite the fact that she has been a farmer without much formal education and she has been suffering from brain paralysis since childhood. Being physically disabled, she can not speak fluently, type effortlessly, or walk steadily. In her words, she is staggering in this staggering world, resorting to poetry as a stick to keep herself from falling. She chose poetry as a form to express herself because it is a literary art that requires much fewer words than prose and novel, and thus lessens the pain for her to write the poems into her notebooks or type her poems onto her weblog, as it takes her great efforts to use her half-paralyzed fingers.

Readers of her poems are not only impressed by the unique beauty displayed in her poetic language but also touched by the strong emotions revealed through her heartfelt words. It is controversial whether her overnight success and sudden popularity are brought about by the power of her poetry or by the compassion of common people who feel sympathetic with her handicap. From my point of view, her poems do carry power to touch the

LAI Peng, Ph.D. in Applied Linguistics, Associate Professor, School of Foreign Languages, Sun Yat-sen University. 
readers and have a different language style from the writing of most contemporary Chinese poets. I noticed the conceptual shift and conceptual collocation in her way of writing, which help to create exceptional conceptual images. Through the words in her poem The Mill (please find the translated version of it in the Appendix A) we can see that she has her own extraordinary way to perceive the world, and I intend to analyze her way of perceptual thinking and poem writing from the conceptual perspective.

\section{Her Conceptual Perception of the World}

YU Xiuhua said in an interview that she is first and foremost a woman, and then a farmer, and at last a poet. Her poems reveal how she perceives the world as a woman and as a farmer. She mainly writes about her life as a woman and as a farmer. She depicts things she sees in the countryside (for example, the mill, the corn, the yard, etc.), which are the most common concrete things, but the way she perceives them is peculiar, as her imagination may instantly lead her from concrete concepts to abstract concepts, which intensely carry her feelings and emotions. Her imagination runs free and takes the readers up high into the sky to embrace the beauty and purity of God Nature, yet her emotions run deep and drag the readers back down to the ground to feel the pain and pleasure of Mother Earth. One reason why her poems draw readers' attention and arouse people's interest might be that her vivid depiction of countryside life evokes nostalgia that is deeply rooted in the hearts of most of the readers, who have been confined to city life much of the time and have been estranged from the countryside life for too long. But that's not the single reason. A more important reason lies in the uniqueness of her perception which I'm going to elaborate on from the conceptual perspective: her exceptional technique in conceptual shift and conceptual collocation, either consciously or subconsciously used in her writing. She perceives the concrete world around her in an abstract way. It is the conceptual shift and collocation between concreteness and abstractness that make her language impressive. It is the conceptual images created by her abstract thinking that make her poems remarkable.

\section{The Conceptual Shift in Her Poems}

YU Xiuhua's poems reflect her unique way of thinking and perceiving. Physically she suffers from brain paralysis, which affects her way of talking and walking, but hasn't had any negative influence on her intellect, as the words in her speeches and poems do make sense and have reached quite great depth in meaning and feeling. But I think this brain disease might have contributed to her unique way of perceiving the world and manipulating the words. In the process of writing she can freely shift between concepts of completely different categories, and readers may marvel at her wild imagination and extraordinary perception, which turn concrete common things into uncommon abstract beings. Through an analysis of some of her representative poems, I found that she most often shifts from concrete concepts to abstract concepts. And it is the depth of abstractness that proves conducive to the linguistic and emotional strength of her poems.

Take her poem The Mill as an example, as we know, what can be fed into the mouth of a mill (to be crushed into powder or liquid) should be something concrete, like grains, corns, etc., as what's written in one line of this poem: "Feed into the mouth of the mill weeds, cockle burs and peanuts". Here "weeds, cockle burs and peanuts" are things concrete that can be ground into tiny pieces by the mill. But in other lines of this poem these concrete things are replaced by things abstract: "Feed into the mouth of the mill indifference of the public and coldness of 
a person”. Here abstract words (“indifference” and "coldness”) have taken the place of concrete words (“weeds” "cockle burs" and "peanuts"). This kind of shift from concrete concepts to abstract concepts not only reveals her unbound imagination but also makes clear her unrestrained emotion. As a disabled person, she felt the indifference of the public and the coldness of somebody towards her, and she wants to crush this kind of aloofness or prejudice into pieces. The replacement of concrete things with abstract things makes readers feel what she felt and become compassionate towards her destiny.

Toward the end of the poem, she wrote: "Who tore away my eye mask, but I went on dragging the mill around, day and night, at the same speed”. In the next part that followed we can see that the mill was abandoned, the mule who dragged the mill was also abandoned (the poet compares herself to the hardworking mule). The person who fed the mill and made the mule drag the mill had left. The mule was actually freed, but it had become habituated to this job and didn't realize it was now free to go, dragging the mill around as always. The poem goes on like this: "A stone fell into the mouth of the deserted mill, and crushed the peach blossoms which were previously fed into it". "Stone" and "peach blossoms" are things concrete. Then the poet's perception of the situation changed into an abstract one as what's shown in the next sentence in her poem: "Just like worldliness fell into the mouth of the deserted mill, and crushed sadness". The shift from concrete things like "stone" and "peach blossoms" to abstract things like "worldliness" and "sadness" helps to reveal the mule’s deep buried sad emotions. The shift from concrete concepts to abstract concepts makes her poem achieve emotional power and enables readers to understand her feelings. Such kind of conceptual shift is frequently used in her poems and shows to the readers her unique perception of things around her.

\section{The Conceptual Collocation in Her Poems}

What's also notable in her poems is the way of "verb-noun" collocation. Some verbs can only go with concrete nouns, but she may use abstract nouns instead. The first line of The Mill is: "Who tied my previous life and my present life to the mill of my hometown?" Here the verb "tie" should have been followed by a concrete noun, as only concrete things can be tied to a mill, but she used abstract nouns like "my previous life" and "my present life" to go with the verb "tie". The collocation of a concrete action "tie" with an abstract concept "my previous/present life" vividly reveals the miserable life of the mule, who was predestined to drag the mill all the time. To "tie" abstract things to a concrete mill, this kind of collocation between concrete action and abstract concepts shows her unique perception of the ordinary mill and her heartfelt sadness towards her pathetic destiny.

Another verb which is repeatedly used in this poem is "feed". In reality we only feed concrete things into the mouth of the mill, like rice, beans and peanuts, etc. But as is shown above, she constantly used abstract nouns to go with the concrete action "feed", like "indifference of the public" "coldness of a person", and even "spring” and "love affair". The unusual "verb-noun” collocation between concepts of completely different categories ("feed spring into the mouth of the mill; feed love affairs into the mouth of the mill”) thus reveals her wild imagination and strong emotion. Even when she used concrete nouns after "feed", it may not be something that we do feed into the mouth of the mill in real life. For example, she used "peach blossoms" "fog” and "snow" after "feed", and thus readers can mentally see an exceptional action of the mill grinding peach blossoms/fog/snow into pieces, this does not seem to make sense in real life, but the extraordinary "verb-noun" collocation creates unique conceptual images which may make the readers envision exceptional pictures and uncommon images. 
In a word, the verb-noun collocation between concrete action and abstract concept (or the verb-noun collocation between concrete action and concrete concept which do not usually go together) may have enabled her poems to achieve originality, as they can reveal the unique way she perceives things and the extraordinary way she looks at her life. The unusual "verb-noun" collocation in her poems depicts conceptual actions which do not really make sense in real life, yet can convey a suppressed emotion deeply rooted in her heart. Such conceptual collocation clearly presents pictures created by her wild imagination and greatly contributes to the readability of her poems.

\section{The Conceptual Self in Her Poems}

The emotion of the poet is also conveyed through the use of first person pronouns in her poems. She uses "I" "me" and "my" quite a lot in her poems, which help to present her personal feelings, although the main character in The Mill is actually not a person, but an animal. In this poem, she perceives herself as the mule who was made to work hard around the mill all the time in order to earn a living. At the beginning of the poem, she asked: "Who tied my previous life and my present life to the mill of my hometown? Who covered my eyes?” Such questioning through the use of "my" from the perspective of a mule reveals her anger at being made only to work but not to see the beauty of Nature or enjoy the happiness of life. In the middle of the poem, she again questioned: "If wind can keep me alive so that I don't have to work, is this anybody's mistake?”. From this sentence, we can hear her indignation: "Why should I be made to work day and night? Is there anything wrong if anybody takes off my eye mask and let me enjoy the beautiful things in life?”. This kind of emotion is conveyed through the use of personal pronouns "me" and "I", which refers to not a person but a mule. The conceptual image of the writer of this poem is thus not a person, a woman, but a mule who is dragging the mill around and around, with pent-up anger and suppressed sadness. The conceptual self as a mule who has emotion but cannot speak is even more touching than the ordinary self as a person who can speak freely about his or her mind.

In the second stanza of the poem, she wrote: "The upper part of the mill that I kept dragging around is bigger than my hometown, and it contains my feelings, my sins, my dreams and my despairs”. Here the repeated use of the "my ___ pattern strongly conveys the mule's various emotions and establishes the conceptual self of the poet as the combination of both a mule and a person.

The last stanza beginning with "Who tore away my eye mask, but I went on dragging the mill around day and night" also shows the conceptual image of herself as a mule through personal pronouns "my" and "I", and as what's shown above, the sentences that followed ("A stone fell into the mouth of the deserted mill, and crushed the peach blossoms which were previously fed into it. Just like worldliness fell into the mouth of the deserted mill and crushed sadness") resorted to conceptual shift from the concrete to the abstract. The technique of building the conceptual self through the "I"/“me"/“my" pronoun and the technique of using conceptual shift from concreteness to abstractness are combined to express the strong emotions of the indignant mule, the personified animal.

\section{The Conceptual Images in Her Poems}

When reading YU Xiuhua's poems, we can feel the beauty of the images created by her words, which activates vivid concepts in our minds, as she integrates whatever she sees in Nature into her poems in such a way 
that we can not only see what she sees, we can also feel what she feels, through the unique way she manipulates the words and creates the images. These images derive from real life yet transcend reality, as they do reflect countryside life yet go far beyond life itself. The conceptual images in her poems help to make her language vivid and touching. For example, in her poem The Mill, things in Nature like "peach blossoms", "weeds”, "cockle burs", "fog" and "snow" were imagined to be fed into the mouth of the mill. When we read this, what comes to our mind is first the beautiful images of these concrete things, which are what we do see in Nature, but are not concepts we may ever relate to the mill. Yet, for such beautiful things to be crushed under the mill, it makes the readers feel not only the beauty, but also the cruelty; not only the suppressed sadness of the mule, but also the restrained anger of the mule, who had to drag the mill around and around without seeing anything. Its eyes were covered, it couldn't see either the beauty or the cruelty, it could only feel the burden of life and the heaviness of the mill. No beautiful spring for the mule to enjoy, no love affair for the mule to experience, that's why the writer of the poem, who compares herself to the mule, imagined for abstract things like "spring" and "love affair" to be fed into the mouth of the mill and to be crushed. Through the conceptual images of "spring" "peach blossoms" and "love affair", readers not only see the beauty and passion of them, but also feel the poet's longing for them and her frustration at not having them. The concrete things she has depicted make readers envision the beauty of such conceptual images, yet the abstract concepts she has used make people feel the uniqueness and originality of her imagination. Such imagination revives the beautiful images of those countryside things ("peach blossoms", "weeds", "cockle burs", etc.) in the nostalgic minds of the readers, but that's not what the poet really meant. The depiction of these concrete outer things is actually meant for deeper revelation of the poet's abstract inner emotions. The conceptual images created by the words in her poems thus not only bring the readers to understand the vulnerable beauty of things in Nature (as they can be crushed under the mill), but also bring them to feel the intense emotion deeply buried at the bottom of the poet's heart.

\section{Conclusion}

All in all, through The Mill as an example, we can see that YU Xiuhua's poems are quite impressive, as she has resorted to frequent conceptual shift and unusual conceptual collocation, which enable her to create extraordinary conceptual images. In her poem The Mill, she didn’t use any traditional rhetoric like simile, etc. Her technique lies in the way she makes use of her conceptual thinking, shifting freely between different conceptual categories to present either concrete or abstract images, to describe things in Nature, to reveal emotions in her heart, and to display pictures in her imagination. She managed to capture the beauty in the outer world and unveil the emotions in her inner heart. The images in her poems contribute to the beauty in her language and make her poems readily acceptable among the public. The sadness in her poems evokes compassion among the readers and makes her respected by fellow Chinese citizens, given that she sticks to writing despite the fact of being handicapped or physically challenged. Although she is unable to speak fluently or walk steadily, she does think quickly and write sensibly. There is a reason to her becoming popular and famous in China just overnight. She earned it through her previous hardwork, which was unknown to the public until 2015. There is a saying: Overnight success usually takes at least 10 years (Jhan \& Hurst, 2008). That's true. She has been writing poems for more than 15 years. She has written more than 2000 poems. And as what's shown above, she has got real techniques in poem writing. Her unique way of perceiving the world enables her to shift freely between concrete 
and abstract concepts. The conceptual aspect of her poems is worth more analysis. Although she is merely a farmer, her persistence in poem-writing and her techniques in word manipulation have brought her to the status of a real poet. In an interview she said that she would appreciate if readers forget about her identity as a farmer, a woman and a handicapped person when they read her writing. Through her poems which have now been published in the form of printed books (YU, 2015b, 2015c), she has now established her new identity as a poet, and a remarkable one, especially from the conceptual perspective, although not all her published poems deserve praise and analysis.

\section{References}

YU, X. H. (2015a). 石磨 (The mill). Retrieved 2016, January 18 from http://cul.qq.com/a/20150118/017767.htm

YU, X. H. (2015b). 摇摇晃晃的人间 (The staggering world). Changsha: 湖南文艺出版社.

YU, X. H. (2015c). 月光落在左手上 (Moonlight on my left hand). Guilin: 广西师范大学出版社.

Jhan, I. T., \& Hurst, I. T. ( 2008). Think a minute. Nanjing: 东南大学出版社.

\section{Appendix A}

\section{The Mill}

(written by YU Xiuhua) (translated by LAI Peng)

Who tied my previous life and my present life to the mill of my hometown

Who covered my eyes

Feed into the mouth of the mill spring, peach blossoms, and transient love affairs

Feed into the mouth of the mill weeds, cockle burs, and peanuts

- If wind can keep me alive so that I don't have to work, is this anybody's mistake

The upper part of the mill that I kept dragging around is bigger than my hometown

My hometown is the lower part of the mill which stood still

The upper part of the mill contains my feelings, my sins, my dreams and my despairs

Feed into the mouth of the mill the indifference of the public and the coldness of a person

Feed into the mouth of the mill fog and snow

— The wind does keep me alive, who has again and again made a mistake

Who tore away my eye mask, but I went on dragging the mill around

Day and night, at the same speed

A stone fell into the mouth of the deserted mill

and crushed the peach blossoms which were previously fed into it

Just like worldliness fell into the mouth of the deserted mill

and crushed sadness

— The mill kept turning and turning, nothing but simply turning 